\title{
SPINAL CORD STIMULATION FOR FAIL BACK SURGERY SYNDROME: LITERATURE REVIEW AND CLINICAL STUDY
}

\author{
ESTIMULACIÓN DE LA MÉDULA ESPINAL PARA EL SÍNDROME DE CIRUGÍA DE ESPALDA \\ FALLIDA: REVISIÓN DE LA LITERATURA Y ESTUDIO CLIINICO
}

\section{ESTIMULAÇÃO DA MEDULA ESPINHAL PARA SÍNDROME DE CIRURGIA DE RETORNO: REVISÃO DA LITERATURA E ESTUDO CLÍNICO}

\author{
Kashcheev Alexey Alexeevich', Gushcha Artem Olegovich'1, Tuurnikov Vladimir Mikhaylovich', Arestov Sergey Olegovich', Vershinin Andrey \\ Vyacheslavovich', Dreval' Maxim Dmitrievich'1 ${ }^{1}$ Poltorako Ekaterina Nikolaevna', Petrosyan David Vazgenovich
}

1. Research Center of Neurology, Department of Neurosurgery, Volokolamskoe Road, Moscow.

\begin{abstract}
Objective: Fail back surgery syndrome (FBSS) is a common cause of pain following spine surgery, and is associated with persistent or recurrent pain despite anatomically correct intervention. Spinal cord stimulation (SCS) is regarded as one of the most effective methods of treatment for fail back surgery syndrome. Methods: We studied 34 patients who underwent test stimulation and chronic SCS for FBSS. Results: Six months postoperatively, mean improvement by the visual analog scale (VAS) of average and maximum daily pain, and the painDETECT score, were $54.4 \%, 50.7 \%$ and $57.3 \%$, respectively. This meets the criteria for effectiveness of the method, according to the literature. Most of patients reported significant improvements in life quality and less need for analgesics. Complications were seen in nine patients (26.4\%) and included: intraoperative dura injury (one patient, $2.9 \%$ ), wound infection (one patient, 2.9\%), and electrode displacement (seven patients, 20.5\%). No cases of postoperative neurological deterioration were seen. Conclusions: SCS is safe and effective for the treatment of neuropathic pain caused by FBSS. Level of Evidence IV; Case series.
\end{abstract}

Keywords: Spinal Cord Stimulation; Neuralgia; Failed Back Surgery Syndrome.

\section{RESUMO}

Objetivos: A síndrome da cirurgia de falência reversa (SAF) é uma causa comum de dor após cirurgia de coluna e associada a dor persistente ou recorrente, apesar da intervenção anatomicamente correta. Estimulação da medula espinhal (SCS) é considerado como um dos métodos mais eficazes de tratamento para a síndrome de cirurgia de retorno. Métodos: Foram estudados 34 pacientes submetidos a estimulação de teste e SCS crônica para FBSS. Resultados: 6 meses de pós-operatório melhora a média de dor diária média e máxima diária na escala análoga visual (VAS), bem como a pontuação do PainDetect foram de 54,4\%, 50,7\% e 57,3\%, respectivamente. Ele atende aos critérios de eficácia do método, de acordo com a literatura. A maioria dos pacientes relatou melhora significativa da qualidade de vida e menor necessidade de analgésicos. As complicações foram observadas em nove pacientes (26,4\%) e incluíram: lesão da dura-máter intraoperatória (um paciente, 2,9\%), infecção da ferida (um paciente, 2,9\%), deslocamento do eletrodo (sete pacientes, 20,5\%). Não houve casos de deterioração neurológica no pós-operatório. Conclusões: A SCS é segura e eficaz para o tratamento da dor neuropática causada pela FBSS. Nível de Evidência IV; Séries de casos.

Descritores: Estimulação da medula Espinal; Neuralgia, Síndrome pós - lamenectomia.

\section{RESUMEN}

Objetivo: El síndrome de cirugía de espalda fallida (FBSS) es una razón común para el dolor después de la cirugía de la columna vertebral y se asocia con dolor persistente o recurrente a pesar de la intervención anatómicamente correcta. La estimulación de la médula espinal (SCS) se considera uno de los métodos de tratamiento más eficaces para el síndrome de cirugía de espalda fallida. Métodos: Se estudiaron 34 pacientes que se sometieron a estimulación de prueba y SCS crónica para FBSS. Resultados: A los seis meses la mejora promedio postoperatoria por la escala visual análoga (EVA) del dolor diario promedio y máximo diario, así como el puntaje de painDETECT fueron 54,4\%, 50,7\% y 57,3\%, respectivamente. Esto cumple con los criterios de efectividad del método, según la literatura. La mayoría de los pacientes informaron una mejoría significativa de la calidad de vida y una menor necesidad de analgésicos. Las complicaciones se observaron en nueve pacientes $(26,4 \%)$ e incluyeron: lesión duramadre intraoperatoria (uno paciente, 2,9\%), infección de la herida (uno paciente, 2,9\%), desplazamiento del electrodo (siete pacientes, 20,5\%). No se observaron casos de deterioro neurológico postoperatorio. Conclusiones: SCS es seguro y efectivo para el tratamiento del dolor neuropático causado por FBSS. Nivel de Evidencia IV; Series de casos.

Descriptores: Estimulación de la médula espinal; Neuralgia; Sindrome de fracaso de la cirugía espinal lumbar. 


\section{INTRODUCTION}

Spine surgery is one of the most rapidly developing fields of modern medicine, and more than 1,000,000 spine operations are currently performed each year, worldwide. ${ }^{1}$ Thanks to minimally invasive, endoscopic and percutaneous technologies, the number of intraoperative and early postoperative complications has decreased and the overall postoperative results have dramatically improved.

Nevertheless, the incidence of late postoperative complications is still high. ${ }^{2}$ One of the main such complications is fail back surgery syndrome (FBSS, or post-laminectomy syndrome), a term that is still controversial. According to different authors, FBSS can be defined as "Persistent or recurrent pain in the back/neck or limbs, despite surgery or treatment thought likely to relieve pain", 3 "Chronic radicular pain that has recurred or persists in the same distribution despite anatomically satisfactory previous spinal surgery", 4,5 "Lumbar (cervical) pain of unknown origin either persisting despite surgical intervention or appearing after surgical intervention for spinal (origin) pain originally in the same topographical distribution". ${ }^{6}$ As a result, we can emphasize that FBSS always has the following characteristics: chronic neuropathic pain, history of spine surgery (or surgeries), absence of clear etiologic factor of pain, and anatomically correct primary spine surgery.

One of the most modern and encouraging methods of treatment for FBSS is spinal cord stimulation (SCS).

\section{METHODS}

Patients with FBSS treated by chronic SCS in the neurosurgical department of the Research Center of Neurology from 2014 to 2017 were prospectively included in our study. All patients signed an Informed Consent Form. The study was approved by the local Ethics Committee of the Research Center of Neurology.

The extended preoperative clinical examination included

- neurological examination (by a neurosurgeon and neurologist, independently);

- medical history;

- visual analog scales (VAS) of pain, painDETECT score, Beck depression inventory;

- magnetic resonance imaging (MRI), computed tomography (CT), dynamic X-Ray;
- neurophysiological examination (electroneuromyography, transcranial magnetic stimulation);

- test X-Ray assisted blockages;

- standard preoperative tests and examinations (blood and urine tests, ECG, chest X-Ray);

- other methods, if needed (densitometry, ultrasound etc).

The Inclusion criteria were as follows:

- neuropathic pain, everyday VAS score $\geq 4$, painDETECT score $\geq 19$;

- no indications for direct revision surgery;

- no effect of correct conservative pain management for 3-6 months (estimated by a neurosurgeon and neurologist, independently). The Exclusion criteria were as follows:

- clear correlation between body position and pain, indications for revision surgery, satisfactory or good effect of conservative pain management;

- radicular or conduction pain;

- severe depression (Beck depression inventory $\geq 20$ ), attempted suicide, mental disorders troubling patient education and/or decreasing compliance;

- severe comorbidities

- negative test stimulation.

All patients underwent two-stage implantation of SCS systems produced by two different manufacturers (St. Jude and Medtronic). The First stage included test stimulation to estimate the coverage and clinical effect of the stimulation.

The epidural space was punctured percutaneously at level L2-L3 under local anesthesia, using a Tuohy needle. The needle position was verified by a common method (loss of resistance) and intraoperative $X$ Ray. An electrode was then implanted using fluoroscopic control at level Th7-Th12, depending on the site of the pain. (Figure 1) The technical feasibility of electrode implantation strongly depended on epidural scarring.

Intraoperative testing was normally performed at a frequency $60 \mathrm{~Hz}$, pulse width $300 \mathrm{msec}$. The results of the intraoperative testing were regarded as positive if the patient felt paresthesia and a feeling of vibration in the region of pain. It is important that these feelings should be tolerable and comfortable for patient. At higher frequencies, muscle fibrillation can be seen in the corresponding group of muscles.

The test electrode was pulled through the counteropening in the lumbar region and fixed by suture. (Figure 2) Patient can walk immediately after surgery.
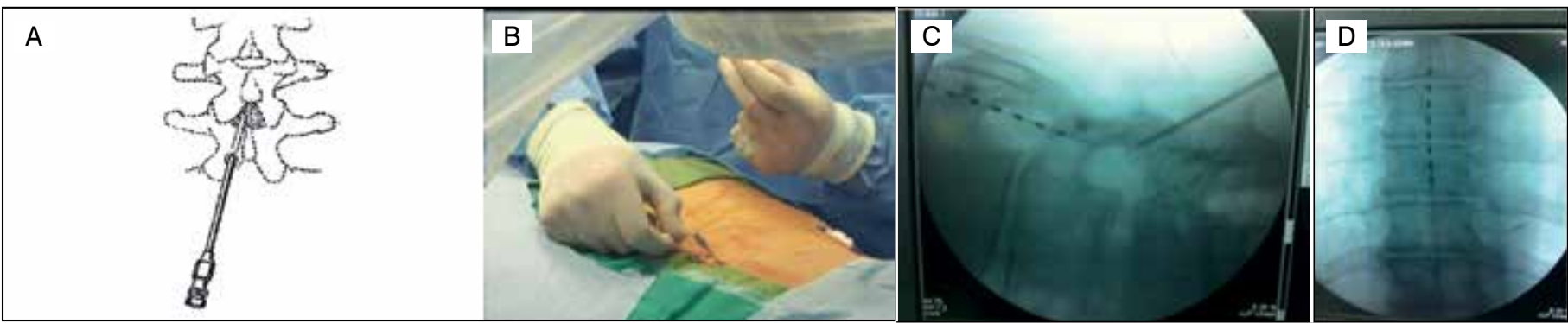

Figure 1. Implantation of test electrode for SCS: A - Needle insertion (angle not more than $30^{\circ}$ ); B - gauge insertion; C, D - electrode is located dorsally on Th9-Th10 (A/P and lateral view).
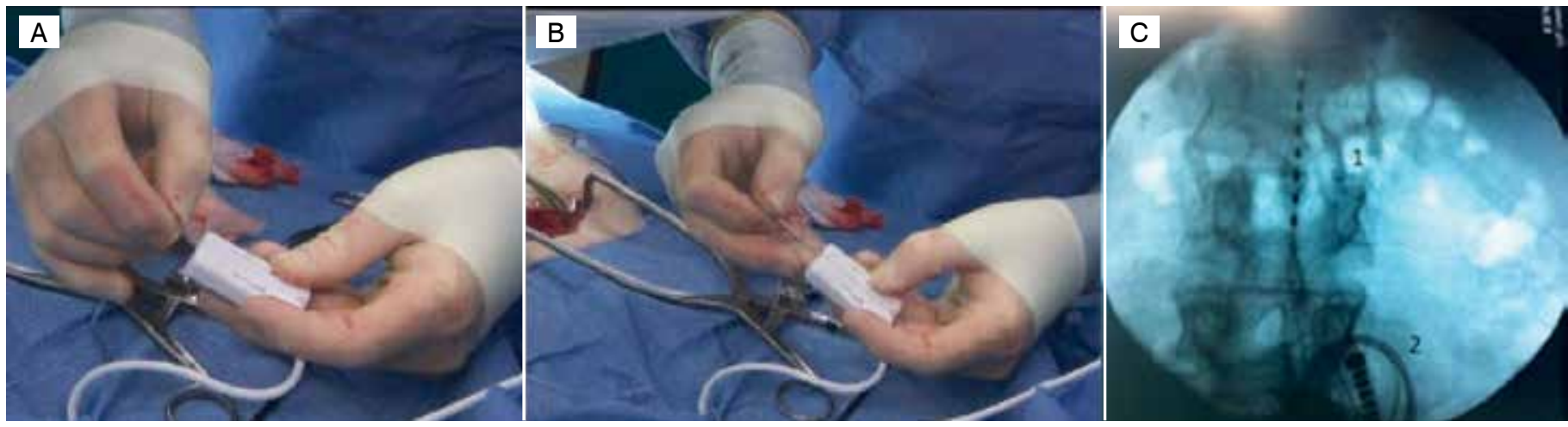

Figure 2. Intraoperative test: A, B - Connection of electrode with extension; C - intraoperative X-Ray (1 - 8 contacts of electrode; 2 - connector of extension) 
During the test period (1-10 days) the results of pain relief were estimated using the pain scales and patient's questionnaire. Reprogramming can also be done if needed. (Figure 3) The main parameters of stimulation are level of perception and level of comfort.

If the test was effective, the second stage (generator implantation) was performed.

The site of electrode insertion was revised and the extension removed. The site of generator implantation ('pocket') was prepared, normally in the right gluteal region (if the patient was right-handed). The generator was connected to the electrode and intraoperative testing, as well as Z-Ray control, were performed. The wounds were closed. (Figure 4) Patient can walk immediately after surgery.

The aim of the postoperative period was to program different modes for stimulation (i.e., for sleeping, walking, the sitting position etc).

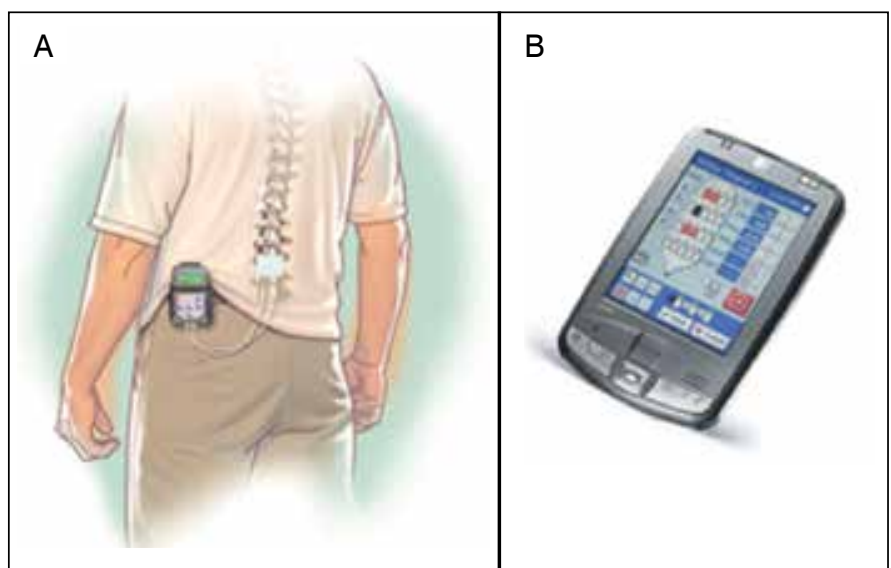

Figure 3. Test period: A - Test electrode and extension are connected to the patient's programmer; B - physician's programmer.

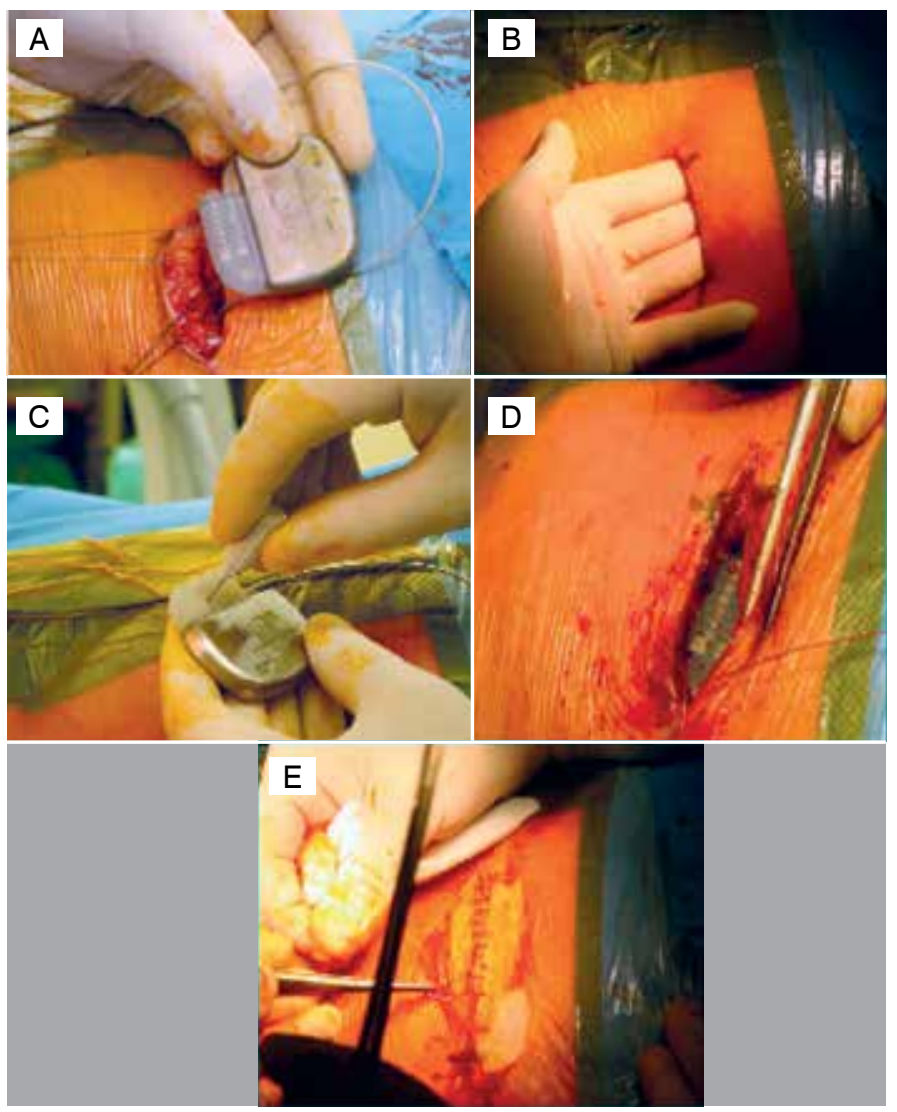

Figure 4. Implantation of permanent system for chronic SCS: A - Generator; B - "Pocket" for generator; C - connection of generator and electrode; D connector; e - wound closure.
The level of comfort depended on the body position during the first two-to-three months postoperatively.

Results were estimated six months postoperatively by following parameters: visual analog scale (VAS) of daily average and maximum daily pain; painDETECT score; postoperative complications.

\section{RESULTS}

Thirty-four patients met the inclusion criteria, were included in the study and operated via both stages of SCS system implantation. Five patients (12.8\% from the primary selection) matched the inclusion criteria but were excluded because of negative test stimulation results.

Nineteen patients (55.8\%) were male, 15 - female (44.2\%); age varied from 29 to 82 years. The number of previous lumbar surgeries was: 1 (11.7\%), 2 (32.3\%), 3 (26.5\%), 4 (17.6\%), 5 (5.9\%), 6 (3.0\%) и 7 (3.0\%). Twenty patients (58.8\%) underwent fusion before SCS.

The mean hospitalization time was 12.9 days.

Six months postoperatively clear pain relief was demonstrated by all three studied parameters. (Table 1)

Complications were seen in nine patients (26.4\%) and included: intraoperative dura injury (one patient, $2.9 \%$ ), wound infection (one patient, 2.9\%), and electrode displacement requiring surgical correction (seven patients, $20.5 \%$ ). No cases of postoperative neurological deterioration were seen.

Tabela 1. Preoperative and postoperative neuropathic pain syndrome

\begin{tabular}{c|c|c|c}
\hline Parameter & $\begin{array}{c}\text { Preoperative } \\
\text { score }\end{array}$ & $\begin{array}{c}\text { Postoperative } \\
\text { score (6 months) }\end{array}$ & $\begin{array}{c}\text { Mean } \\
\text { improvement }\end{array}$ \\
\hline $\begin{array}{c}\text { VAS: daily average } \\
\text { pain }\end{array}$ & $5-9(6.8)$ & $0-7(3.1)$ & $54.4 \%$ \\
\hline $\begin{array}{c}\text { VAS: daily } \\
\text { maximum pain }\end{array}$ & $5-9(7.1)$ & $0-7(3.5)$ & $50.7 \%$ \\
\hline Pain detect & $19-36(27.2)$ & $3-20(11.6)$ & $57.3 \%$ \\
\hline
\end{tabular}

\section{DISCUSSION}

According to relevant clinical studies, fail back surgery syndrome (FBSS) is a common condition with prevalence ranging from 10\% to $40 \%{ }^{7}$ FBSS develops around 4.7 years after primary surgery. ${ }^{8}$ FBSS significantly decreases quality of life, and leads to multiple revisions (rate of revisions - 4\%-19\%), ${ }^{9}$ chronic pain, depression, medical and social impairment, disability and the need for of medical treatment. Patients with FBSS permanently take antidepressants (38\%), anticonvulsants (38\%), and opioid analgesics (62\%), ${ }^{10} 86 \%$ of patients have to use more than four methods of conservative management simultaneously. ${ }^{11}$ As a result, FBSS is a serious medical and social problem.

Multiple studies have shown effectiveness of SCS for FBSS. To date, after SCS was invented by CN Shealy in 1967 more than 200,000 SCS systems have implanted worldwide, with more than 25,000 implanted each year. ${ }^{12,13}$ FBSS is one of the most evidence-based indications for SCS. ${ }^{14} \mathrm{~A}$ prospective, randomized, multicenter, international, controlled study EVIDENCE trial of 132 patients with FBSS showed stable pain relief in leg or legs (more than 50\% from baseline) 6-24 months postoperatively. ${ }^{15}$ The multicenter, randomized PROCESS trial demonstrated pain relief of $50 \%-70 \%$ and a statistically significant reduction of drug intake. ${ }^{16}$ RB North et al. showed that in USA SCS for FBSS is $17-53 \%$ less expensive and more effective than reoperation. ${ }^{17}$ Retrospective studies (410 patients) also showed that $60 \%$ of patients had pain relief of more than $50 \% .{ }^{18}$ Available data in the Russian literature confirm these results: SCS was effective in early and late periods with a more than $75 \%$ decrease in analgesic drug intake in a group of more than 100 patients operated at the Neurosurgical 
Institute named after N.N. Burdenko. ${ }^{19}$ Another study on 45 patients showed that SCS is more effective than conservative pain management for SCS. ${ }^{20}$

Our results are comparable with those of other authors; pain relief varies from $50 \%$ to $60 \%$ depending on the measurement scale used. According to common opinion, test stimulation effectiveness of less than $50 \%$ should be regarded as a negative result. Nevertheless 4 of our 34 patients had less than $50 \%$ pain relief during the test, but claimed that they wanted the whole SCS system to be implanted as even this pain relief is still important for their quality of life. In some of our patients pain relief in the initial months after implantation was higher than in long-term; this can be explained by phenomenon of neural tolerance, and corresponds to the finding of Isagulyan ID, Tomsky AA et al. ${ }^{21}$ The rate of technical complications in our group was fairly high (20.5\%). This can be explained by learning curve that our surgical team underwent: most complications were seen during $1^{\text {st }}$ year of mastering the SCS technique. It is interesting that in all patients with long fusions for deformity correction, it was feasible to implant the electrode percutaneously and avoid open surgery.

\section{CONCLUSIONS}

SCS is an effective method of the treatment for intractable neuropathic pain caused by FBSS. Chronic SCS led to $\geq 50 \%$ pain relief, significantly improved quality of life, reduced the need for analgesic medications, and helped avoid unnecessary revisions. Adherence to strict indications and precise patient selection are crucial for successful SCS. Neurostimulation in most cases is safe for the patient, and technically feasible; complications include electrode migration, which can be easily corrected. New methods of stimulation such as high-frequency stimulation and non-invasive external generators will improve the results of treatment and decrease the rate of complications. Long-term results of SCS for FBSS should be estimated, while enlarging the study group. We presume that patients with FBSS require a multidisciplinary approach, with the participation of neurosurgeons, neurologists, orthopedists, rehabilitation specialists and other staff.

All authors declare no potential conflict of interest related to this article.

CONTRIBUTION OF THE AUTHORS: Each author made significant individual contributions to this manuscript. AG $(0000-0003-3451-5750)^{*}$ and AK (0000-0001-7681-3073)* were the main contributors to the drafting of the manuscript. AG and AK carried out the surgery, followed up patients and gathered clinical data. AK and AG evaluated the data from the statistical analysis. VT (0000-0003-4881-4241)*, SA (0000-0003-4809-4117)*, AV (0000-0002-80061334) ${ }^{\star}, \mathrm{MD}(0000-0002-7839-309 X)^{\star}$, EP (0000-0001-9208-2987)* and DP (0000-0001-9588-7721)* performed the literature search and review of the manuscript, and contributed to the intellectual concept of the study. ${ }^{*}$ ORCID (Open Researcher and Contributor ID).

\section{REFERENCES}

1. Tulkin ON, Nazarov AS, Davydov EA, Bersnev VP. Characteristics of clinical presentations of Failed Back Surgery Syndrome. Translational Medicine. 2015;2(3):31-2.

2. Taylor RS. Epidemiology of refractory neuropathic pain. Pain Pract. 2006;6(1):22-6.

3. Kumar K, Taylor RS, Jacques L, Eldabe S, Meglio M, Molet J et al. Spinal cord stimulation versus conventional medical management for neuropathic pain: a multicentre randomised controlled trial in patients with failed back surgery syndrome. Pain. 2007:132(1-2):179-88.

4. Kumar K, Taylor RS, Jacques L, Eldabe S, Meglio M, Molet J et al. The effects of spinal cord stimulation in neuropathic pain are sustained: a 24-month follow-up of the prospective randomized controlled multicenter trial of the effectiveness of spinal cord stimulation. Neurosurgery. 2008;63(4):762-70.

5. Leveque JC, Villavicencio AT, Rubin L, Bulsara K, Gorecki JP. Spinal cord stimulation for failed back surgery syndrome. Neuromodulation. 2001:4(1):1-9.

6. Merskey H, Bogduk N. Lumbar spinal or radicular pain after failed spinal surgery. In: Merskey H, Bogduk, N, editors. Classification of Chronic Pain. Seattle: IASP Press; 1994. p. 179.

7. Hoy D, Brooks P, Blyth F, Buchbinder R. The epidemiology of low back pain. Best Pract Res Clin Rheumatol. 2010;24(6):769-81.

8. Follet KA, Dirks BA. Etiology and evaluation of the failed back surgery syndrome. Neurosurg Q. 1993;3(1):40-59.

9. Durand G, Girodon J, Debiais F. Medical management of failed back surgery syndrome in Europe: evaluation modalities and treatment proposals. Neurochirurgie. 2015;61(Suppl 1):S57-65.

10. Thomson S, Jacques L. Demographic characteristics of patients with severe neuropathic pain secondary to failed back surgery syndrome. Pain Pract. 2009;9(3): 206-15.

11. Ragab A, Deshazo RD. Management of back pain in patients with previous back surgery. Am J Med. 2008:121(4):272-8.

12. Shealy CN, Mortimer JT, Reswick JB. Electrical inhibition of pain by stimulation of the dorsal columns: preliminary clinical report. Anesth Analg. 1967;46(4):489-91.
13. Kreis P, Fishman S. Spinal cord stimulation percutaneous implantation techniques. New York: Oxford University Press: 2009

14. Isagulyan ED, Shabalov VA. Chronic Spinal Cord Stimulation in treatment of Failed Back Surgery Syndrome. Hirurgia Pozvonochnika. 2015;12(3):33-43.

15. North RB, Kumar K, Wallace MS, Henderson JM, Shipley J, Hernandez J et al. Spinal Cord Stimulation versus re-operation in patients with failed back surgery syndrome: an international multicenter randomized controlled trial (EVIDENCE study). Neuromodulation. 2011:14(4):330-5.

16. Kumar K, North R, Taylor R, Sculpher M, den Abeele C, Gehring M et al. Spinal Cord Stimulation vs. Conventional Medical Management: A Prospective, Randomized, Controlled, Multicenter Study of Patients with Failed Back Surgery Syndrome (PROCESS Study). Neuromodulation. 2005;8(4):213-8.

17. North RB, Kidd D, Shipley J, Taylor RS. Spinal cord stimulation versus reoperation for failed back surgery syndrome: a cost effectiveness and cost utility analysis based on a randomized, controlled trial. Neurosurgery. 2007;61(2):361-8.

18. Kumar K, Hunter G, Demeria D. Spinal cord stimulation in treatment of chronic benign pain: challenges in treatment planning and present status, a 22-year experience. Neurosurgery. 2006;58(3):481-96.

19. Isagulyan ED, Tomskij AA, Shabalov VA, Salova EM. Chronic electrical stimulation of the spinal cord for failed back surgery syndrome. Hirurgiâ Pozvonocnika. 2015;12(3):33-43.

20. Morozov IN, Ushakov Al. Neuromodulation for Refractory Failed Back Surgery Syndrome Patients. Sovremennyje technologii v medicine. 2015;7(3):90-4.

21. Isagulyan ED, Tomsky AA, Dekopov AV, Salova EM, Troshina EM, Dorokhov EV, et al. Results of motor cortex stimulation in the treatment of chronic pain syndromes]. Zh Vopr Neirokhir Im N N Burdenko. 2015;79(6):46-60. 